\title{
RESEARCH ON THE RELATIONSHIP BETWEEN SPORTS SCIENTIFIC TRAINING AND ATHLETES' MENTAL HEALTH
}

\author{
PESQUISA SOBREA RELAÇÃO ENTRE O TREINAMENTO CIENTÍFICO DO ESPORTEEA SAÚDE MENTAL \\ DEATLETAS
}

\begin{abstract}
INVESTIGACIÓN SOBRE LA RELACIÓN ENTRE EL ENTRENAMIENTO CIENTÍFICO DEPORTIVO Y LA SALUDMENTAL DE LOS DEPORTISTAS
\end{abstract}

\begin{abstract}
Fuling $\operatorname{Han}^{1}$ (D)
(Physical Education Professional)

1. Institute of Physical Education, Shandong University of Finance and Economics, Jinan, China.
\end{abstract}

\section{Correspondence:}

Fuling Han

Institute of Physical Education,

Shandong University of Finance and Economics, Jinan, 250000,

China. hanfuling6102@163.com

\begin{abstract}
Introduction: Regarding sports mental fatigue research, foreign countries mainly discuss the theoretical model of mental exhaustion. Among them, Silva's theoretical model believes that sports mental fatigue is a negative training stress response. Domestic research mainly analyzes and discusses the concept, causes, and monitoring of mental fatigue. Objective: This study explores the relationship between sports fatigue and mental health of elite athletes through investigation and analysis; analyzes whether social support plays a moderating role in training stress and how aspect support plays an important role. Methods: Based on the stress theory and the negative training stress response model theory, the paper used the Mental Health Inventory (PHI), Athlete Exercise Fatigue Questionnaire, Social Support Rating Scale, and Perceived Social Support Scale to analyze 163 outstanding athletes above the first level. Carry out investigation, use SPSS10.0 software to carry out reliability analysis, Pearson correlation analysis, and multiple linear stepwise regression analysis. Results: The mental health level of elite athletes is closely related to the degree of sports fatigue, and the correlation coefficients between most factors have reached a significant level. The physical (emotional) exhaustion in sports fatigue is an important predictor of the mental health of elite athletes; age, sports grade, economic conditions, perceived family support, and mental health are important predictors of sports fatigue for elite athletes; social support is an important external "buffer" in the process of training stress, in which family support and emotional support play a major regulatory role. Conclusions: The research results can provide references for maintaining and promoting athletes' physical and mental health, provide some useful references for mental health education of sports teams, and provide empirical data for sports psychology and health psychology. Level of evidence II; Therapeutic studies - investigation of treatment results.
\end{abstract}

Keywords: Physical conditioning, human; Mental health; Social support; Fatigue; Athletes.

\section{RESUMO}

Introdução: Em relação à pesquisa sobre fadiga mental no esporte, os países estrangeiros discutem principalmente o modelo teórico de esgotamento mental. Entre eles, o modelo teórico de Silva acredita que a fadiga mental esportivaé uma resposta negativa ao estresse do treinamento. A pesquisa doméstica examina e discute principalmente o conceito, as causas e o monitoramento da fadiga mental. Objetivo: Este estudo explora a relação entre fadiga esportiva e saúde mental em atletas de elite por meio de pesquisa e análise; se o suporte social desempenha um papel moderador no treinamento de estresse e como os suportes de aparência desempenham um papel importante. Métodos: Com base na teoria do estresse e na teoria do modelo de resposta negativa ao estresse do treinamento, o artigo utilizou o Mental Health Inventory (PHI), o Athlete Exercise Fatigue Questionnaire, a Social Support Rating Scale e a Perceived Social Support Scale para analisar 163 atletas de destaque. Realizamos uma investigação e usamos o software SPSS10.0 para realizar a análise de confiabilidade, a análise de correlação de Pearson e a análise de regressão linear múltipla stepwise. Resultados: O nivel de saúde mental de atletas de elite está intimamente relacionado ao grau de fadiga esportiva, e os coeficientes de correlação entre a maioria dos fatores atingiram um nivel significativo. A exaustão física (emocional) na fadiga esportiva é um importante preditor de saúde mental em atletas de elite; idade, nivel atlético, condições econômicas, apoio familiar percebido e saúde mental são importantes preditores de fadiga esportiva para atletas de elite; O suporte social é um importante "amortecedor" externo no processo de treinamento do estresse, no qual o suporte familiar e emocional desempenham um papel regulador importante. Conclusiones: Los resultados de la investigación pueden proporcionar referencias para mantener y promover la salud física y mental de los atletas, proporcionar algunas referencias útiles para la educación en salud mental de los equipos deportivos y proporcionar datos empíricos para la psicología del deporte y la psicología de a saúde. Nível de evidência ll; Estudos terapêuticos: investigação dos resultados do tratamento.

Descritores: Condicionamento físico humano; Saúde mental; Apoio social; Fadiga; Atletas. 


\section{RESUMEN}

Introducción: En cuanto a la investigación sobre la fatiga mental deportiva, los países extranjeros discuten principalmente el modelo teórico del agotamiento mental. Entre ellos, el modelo teórico de Silva cree que la fatiga mental deportiva es una respuesta negativa al estrés del entrenamiento. La investigación doméstica examina y discute principalmente el concepto, las causas y el seguimiento de la fatiga mental. Objetivo: Este estudio explora la relación entre la fatiga deportiva y la salud mental de los deportistas de élite a través de la investigación y el análisis; si el apoyo social juega un papel moderador en el entrenamiento del estrés y cómo los apoyos de aspecto juegan un papel importante. Métodos: Basado en la teoría del estrés y la teoría del modelo de respuesta negativa al estrés del entrenamiento, el documento utilizó el Inventario de Salud Mental (PHI), el Cuestionario de Fatiga del Ejercicio del Atleta, la Escala de Calificación de Apoyo Social y la Escala de Apoyo Social Percibido para analizar 163 atletas destacados. Realizamos una investigación, y utilizamos el software SPSS10.0 para realizar análisis de confiabilidad, análisis de correlación de Pearson y análisis de regresión lineal múltiple por pasos. Resultados: El nivel de salud mental de los deportistas de élite está estrechamente relacionado con el grado de fatiga deportiva, y los coeficientes de correlación entre la mayoría de factores han alcanzado un nivel significativo. El agotamiento fisico (emocional) en la fatiga deportiva es un importante predictor de la salud mental de los deportistas de élite; la edad, el nivel deportivo, las condiciones económicas, el apoyo familiar percibido y la salud mental son predictores importantes de la fatiga deportiva para los atletas de élite; El apoyo social es un importante "amortiguador" externo en el proceso de entrenamiento del estrés, en el que el apoyo familiar y el apoyo emocional juegan un papel regulador importante. Conclusiones: Los resultados de la investigación pueden proporcionar referencias para mantener y promover la salud física y mental de los atletas, proporcionar algunas referencias útiles para la educación en salud mental de los equipos deportivos y proporcionar datos empíricos para la psicología del deporte y la psicología de la salud. Nivel de evidencia Il; Estudios terapéuticos: investigación de los resultados del tratamiento.

Descriptores: Acondicionamiento físico humano; Salud mental; Apoyo social; Fatiga; Atletas.

\section{INTRODUCTION}

This study explores the relationship between sports fatigue and mental health of elite athletes through investigation and analysis; analyzes whether social support plays a moderating role in training stress, and from which aspect of support plays an important role; pays attention to mental health and sports fatigue Individual differences, through multiple regression analysis to explore the impact of demographic variables such as gender, age, education level, sports skill level, family economic status and social support on mental health and sports fatigue. ${ }^{1}$

\section{METHOD}

\section{Research object}

The thesis selected some elite athletes above the first level in a certain province as the research object. A total of 180 questionnaires were distributed. After excluding the PHI 3 validity scales with scores above 70 and other questionnaires with incomplete answers, 163 questionnaires were valid, and the effective recovery rate was $90.5 \%$. The average age is 19.88 years old, of which 88 are males and 75 are females; 17 are in water sports (kayaking, rowing), 36 are heavy athletics (wrestling, weightlifting, judo, taekwondo, kicks), 18 are martial arts routines, There are 28 swimmers, 16 table tennis, 18 Sanda, 6 Taijiquan, nine baseballs, 15 track, and field; 46 athletes, 117 first-level athletes; 10 people with better family economic conditions, 131 people in general, 22 are poor; 80 have a bachelor degree, 15 have a college degree, 65 have a high school degree, and 3 have a high school degree or less.

\section{Research tools}

\section{Assessment of mental health}

The paper uses the Mental Health Checklist (PHI) in the WJZ psychological test and statistical software system of the Chinese Social Psychological Society, which contains 168 questions; it is divided into seven clinical scales and three validity scales. In this study, the scale's internal consistency coefficient was 0.88 , and the split-half reliability was 0.85 .

\section{Sports fatigue assessment}

The thesis adopts the "Athlete Sports Fatigue Questionnaire" revised by Raedeke and Smith. There are 15 questions in total divided into three dimensions: emotional (physical) exhaustion, reduced sense of achievement, and negative sports evaluation. Yes," evaluate yourself on five levels. The higher the score of each dimension, the higher the degree of fatigue. Cross-sample validity and test-retest reliability are relatively high in foreign studies. ${ }^{2}$ In this study, the scale's internal consistency coefficient is 0.79 , and the split-half reliability is 0.81 .

\section{Social support evaluation}

The thesis uses the "Social Support Rating Scale (SSRS)" compiled by Xiao Shuiyuan, with a total of 10 topics, including objective support, emotional support, and the utilization of support, as well as the total support score. The scale has been applied in more than 20 domestic studies and has good reliability and validity. In this study, the scale's internal consistency coefficient was 0.77 , and the split-half reliability was 0.78 .

\section{Comprehend social support assessment}

The paper uses the Perceived Social Support Scale (PSSS) compiled by Zimet, with a total of 12 topics, including the three dimensions of Perceived Family Support, Perceived Friends Support, Perceived Other Supports, and Perceived Support Total Score. In this study, the scale's internal consistency coefficient was 0.82, and the split-half reliability was 0.78 .

\section{Testing and data processing}

This questionnaire survey was distributed after the end of the 10th Games in a province in 2006. Specially trained researchers will organize the test personally and conduct the group test with coaches or managers'assistance. The test will first read the instructions and precautions. The questionnaire was returned on the spot after the test. SPSS10.0 software was used for reliability test, Pearson correlation analysis, and multiple linear stepwise regression analysis. ${ }^{3}$ 
Human body motion coordinate system

The motion coordinate system is related to the component to be studied. For example, on component 4, the coordinate origin passes through the center of mass of the component, and the Z-axis is parallel to the axis direction of the component; the $X$-axis is parallel to the distal kinematic pair (on the same component, away from the movement transmitted by the motion).

$$
[x y z]^{T}=[\gamma][\beta][\alpha][X Y Z]^{T}
$$

In the above formula, the $[\gamma][\beta][\alpha]$ in the transformation matrix are:

$[\gamma]=\left[\begin{array}{ccc}1 & 0 & 0 \\ 0 & \cos \gamma & \sin \gamma \\ 0 & -\sin \gamma & \cos \gamma\end{array}\right]$

$[\beta]=\left[\begin{array}{ccc}\cos \beta & 0 & -\sin \beta \\ 0 & 1 & 0 \\ \sin \beta & 0 & \cos \beta\end{array}\right]$

$[\alpha]=\left[\begin{array}{ccc}1 & 0 & 0 \\ 0 & \cos \alpha & \sin \alpha \\ 0 & -\sin \alpha & \cos \alpha\end{array}\right]$

The inverse matrix of equation (1) is:

$$
[X Y Z]^{T}=[\alpha]^{T}[\beta]^{T}[\gamma]^{T}[x z y]^{T}
$$

The formula $[\alpha]^{T}[\beta]^{T}[\gamma]^{T}$ represents the transposed matrix of the matrix $[\alpha],[\beta]$, and $[\gamma]$, respectively.

Equations (1) and (2) coordinate transformation formulas between the moving coordinate system and the static coordinate system in the body kinematics model. In the human body mechanism diagram, each component's movement can be divided into rotational movement and linear movement. Each component's position is represented by the position of the center of mass and Euler angle relative to the origin of the static coordinate. ${ }^{4}$ Therefore, the component's angular velocity can be expressed by the differential value of the Euler angle. The angular velocity of the component is

$$
\left[\omega_{x} \omega_{y} \omega_{z}\right]^{T}=[\gamma][\beta][\alpha 00]^{T}+[\beta][0 \beta 0]^{T}+[\gamma 00]^{T}
$$

After finishing the above formula, we can get:

$$
\left[\omega_{x} \omega_{y} \omega_{z}\right]^{T}=[p][\alpha \beta \gamma]^{T}
$$

In the formula $[p]=\left[\begin{array}{ccc}\cos \beta & 0 & 1 \\ \sin \beta \sin \gamma & \cos \gamma & 0 \\ \sin \beta \cos \lambda & -\sin \gamma & 0\end{array}\right]$. The paper assumes

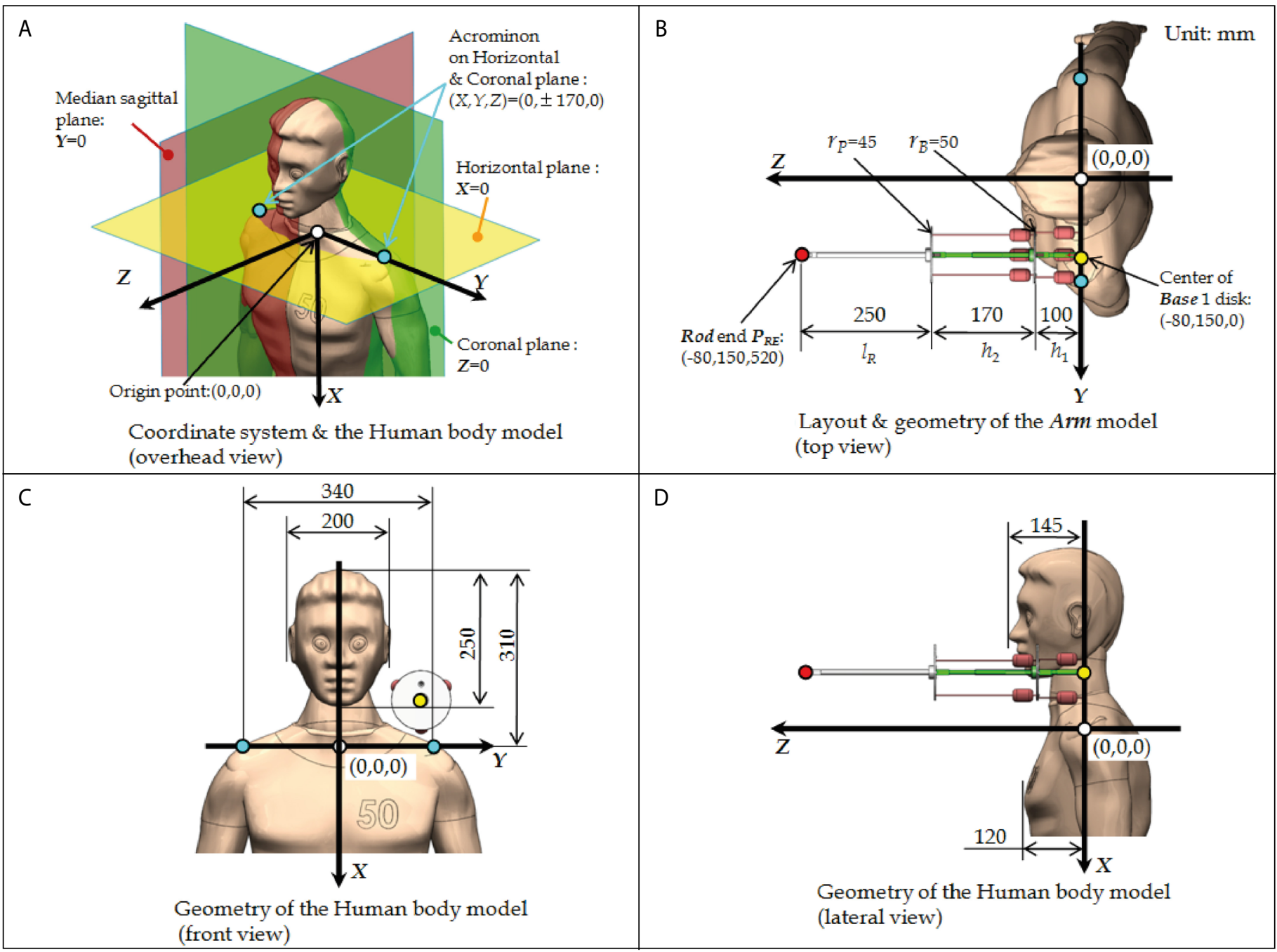

Figure 1. Human body coordinate system. 
that $\omega_{X}, \omega_{Y}, \omega_{Z}$ is the angular velocity of the component around the $X$-axis, $Y$-axis, and $Z$-axis of the static coordinate system, then

$$
\left[\omega_{X} \omega_{Y} \omega_{Z}\right]^{T}=[\alpha]^{T}[\beta]^{T}[\gamma]^{T}[p][\alpha \beta \gamma]^{T}
$$

The angular acceleration $\varepsilon_{x} \varepsilon_{y} \varepsilon_{z}$ of the component moving around the coordinate system $\mathrm{x}$-axis, $\mathrm{y}$-axis, and the $z$-axis is:

$$
\left[\varepsilon_{x} \varepsilon_{y} \varepsilon_{z}\right]^{T}=\left[\omega_{x} \omega_{y} \omega_{z}\right]^{T}=\frac{d}{d t}\left[\omega_{x} \omega_{y} \omega_{z}\right]^{T}
$$

which is

$$
\left[\varepsilon_{x} \varepsilon_{y} \varepsilon_{z}\right]^{T}=\frac{d}{d t}\left([p][\alpha \beta \gamma]^{T}\right)
$$

The angular acceleration $\varepsilon_{X} \varepsilon_{Z} \varepsilon_{Y}$ of the component around the $X$-axis, $Y$-axis, and Z-axis of the static coordinate system is:

$$
\left[\varepsilon_{X} \varepsilon_{Z} \varepsilon_{Y}\right]^{T}=\frac{d}{d t}\left([\alpha]^{T}[\beta]^{T}[\lambda]^{T}[p]^{T}[\alpha \beta \gamma]^{T}\right)
$$

\section{RESULTS}

\section{The relationship between sports fatigue and mental health}

It can be seen from Table 1 that various factors of sports fatigue are positively correlated with various factors of mental health. Except for the decline in the sense of accomplishment, which is not significantly correlated with detachment factors from reality and the state of excitement, there is a significant positive correlation among the rest. ${ }^{5}$ Among them, the decline in the sense of accomplishment has an extremely significant positive correlation with depression factors, physical (emotion) exhaustion and somatization, depression, anxiety, pathological personality, doubts, negative evaluation of exercise and somatization factors, etc. $(P<0.001)$.

\section{The relationship between social support and mental health}

It can be seen from Table 2 that, except for the positive correlation with the excitement factor, the social support factors are negatively correlated with other factors; the social support factors are not significantly related to the somatization factor but are significantly related to the suspicious factor. Some factors are significantly related to other mental health factors. ${ }^{6}$ Among them, objective support and doubt, emotional support and social support total score and anxiety, doubt, support utilization and excitement, comprehension family support and comprehension support total score and depression, anxiety, morbid personality, suspiciousness, detachment from reality, there is extremely significant Negative correlation $(P<0.01)$.

Table 1. The correlation between sports fatigue and mental health.

\begin{tabular}{c|c|c|c|c}
\hline \multicolumn{2}{c|}{} & \multicolumn{3}{|c}{ Sports fatigue } \\
\cline { 2 - 5 } & $\begin{array}{c}\text { Decreased } \\
\text { sense of } \\
\text { accomplishment }\end{array}$ & $\begin{array}{c}\text { Physical, } \\
\text { emotional } \\
\text { exhaustion }\end{array}$ & $\begin{array}{c}\text { Negative } \\
\text { evaluation } \\
\text { of sports }\end{array}$ \\
\hline \multirow{4}{*}{ psychological } & Somatization & $0.163^{\mathrm{a}}$ & $0.312^{c}$ & $0.281^{c}$ \\
\cline { 2 - 5 } & Depression & $0.294^{c}$ & $0.269^{c}$ & $0.212^{\mathrm{b}}$ \\
\cline { 2 - 5 } & $\begin{array}{c}\text { anxiety } \\
\text { personality }\end{array}$ & $0.212^{\mathrm{a}}$ & $0.363^{c}$ & $0.176^{\mathrm{a}}$ \\
\cline { 2 - 5 } & suspicion & $0.175^{\mathrm{a}}$ & $0.285^{\mathrm{c}}$ & $0.256^{\mathrm{b}}$ \\
\cline { 2 - 5 } & $\begin{array}{c}\text { Divorced } \\
\text { from reality }\end{array}$ & 0.113 & $0.296^{c}$ & $0.242^{\mathrm{b}}$ \\
\cline { 2 - 5 } & Excited-state & 0.109 & $0.237^{\mathrm{b}}$ & $0.169^{\mathrm{a}}$ \\
\hline
\end{tabular}

The relationship between social support and sports fatigue

It can be seen from Table 3 that the factors of social support are negatively correlated with the factors of exercise fatigue. Among them, except that objective support is not significantly related to the decline in the sense of accomplishment, other social support factors have a very significant negative correlation with the decline in the sense of accomplishment; There are a very significant negative correlation between family support, physical (emotional) exhaustion and negative evaluation of exercise, $\mathrm{P}<0.0 \mathrm{O}$.

\section{Multiple regression analysis of sports fatigue, social support, and demographic variables on mental health}

The thesis uses the mental health factors to be divided into dependent variables. It uses 16 variables such as sports fatigue factors, social support factors, gender, age, education level, and family economic status as independent variables. It conducts multiple linear stepwise regression analysis (Stepwise method), using F-test as the criterion for screening variables. As a result, three independent variables entered the equation, and three models were established. Model 3 has the highest coefficient of determination, and the analysis of variance has reached a significant level, as shown in Table 4.

Table 2. The correlation between social support and mental health.

\begin{tabular}{c|c|c|c|c|c|c}
\hline & Somatization & Depression & anxiety & suspicion & $\begin{array}{c}\text { Divorced } \\
\text { from } \\
\text { reality }\end{array}$ & $\begin{array}{c}\text { Excited } \\
\text { state }\end{array}$ \\
\hline $\begin{array}{c}\text { Objective } \\
\text { support }\end{array}$ & -0.086 & $-0.206^{a}$ & -0.136 & $-0.258^{c}$ & $-0.175^{a}$ & 0.052 \\
\hline $\begin{array}{c}\text { Subjective } \\
\text { support }\end{array}$ & -0.085 & $-0.190^{\mathrm{a}}$ & $-0.289^{c}$ & $-0.349^{c}$ & $-0.226^{\mathrm{b}}$ & $0.193^{\mathrm{a}}$ \\
\hline $\begin{array}{c}\text { Support } \\
\text { utilization }\end{array}$ & -0.117 & -0.113 & -0.107 & $-0.191^{\mathrm{a}}$ & -0.08 & $0.267^{c}$ \\
\hline $\begin{array}{c}\text { Social support } \\
\text { total score }\end{array}$ & -0.125 & $-0.243^{\mathrm{b}}$ & $-0.277^{c}$ & $-0.391^{c}$ & $-0.244^{\mathrm{b}}$ & $0.224^{\mathrm{b}}$ \\
\hline $\begin{array}{c}\text { Comprehend } \\
\text { friend support }\end{array}$ & -0.023 & $-0.165^{\mathrm{a}}$ & $-0.175^{\mathrm{a}}$ & $-0.258^{\mathrm{b}}$ & -0.099 & 0.123 \\
\hline $\begin{array}{c}\text { Comprehend } \\
\text { other support }\end{array}$ & -0.032 & $-0.173^{\mathrm{a}}$ & -0.142 & $-0.245^{\mathrm{b}}$ & -0.124 & $0.202^{\mathrm{b}}$ \\
\hline $\begin{array}{c}\text { Understanding } \\
\text { family support }\end{array}$ & -0.124 & $-0.319^{c}$ & $-0.301^{c}$ & $-0.302^{c}$ & $-0.243^{\mathrm{b}}$ & 0.104 \\
\hline $\begin{array}{c}\text { Comprehend } \\
\text { support } \\
\text { total score }\end{array}$ & -0.08 & $-0.284^{c}$ & $-0.268^{c}$ & $-0.343^{c}$ & $-0.203^{\mathrm{b}}$ & 0.083 \\
\hline
\end{tabular}

Remarks: $a: P<0.05 ; b: P<0.01 ; c: P<0.001$.

Table 3. The relationship between social support and sports fatigue.

\begin{tabular}{c|c|c|c}
\hline & $\begin{array}{c}\text { Decreased sense of } \\
\text { accomplishment }\end{array}$ & $\begin{array}{c}\text { Physical, emotional } \\
\text { exhaustion }\end{array}$ & $\begin{array}{c}\text { Negative evaluation } \\
\text { of sports }\end{array}$ \\
\hline $\begin{array}{c}\text { Objective } \\
\text { support }\end{array}$ & -0.102 & -0.08 & -0.152 \\
\hline $\begin{array}{c}\text { Subjective } \\
\text { support }\end{array}$ & $-0.218^{\mathrm{b}}$ & -0.008 & 0.074 \\
\hline $\begin{array}{c}\text { Support } \\
\text { utilization }\end{array}$ & $-0.217^{\mathrm{b}}$ & -0.069 & -0.074 \\
\hline $\begin{array}{c}\text { Social support } \\
\text { total score }\end{array}$ & $-0.220^{\mathrm{b}}$ & -0.059 & -0.037 \\
\hline $\begin{array}{c}\text { Comprehend } \\
\text { friend support }\end{array}$ & $-0.214^{\mathrm{b}}$ & -0.024 & -0.004 \\
\hline $\begin{array}{c}\text { Comprehend } \\
\text { Other support }\end{array}$ & $-0.249^{\mathrm{b}}$ & -0.008 & -0.062 \\
\hline $\begin{array}{c}\text { Understanding } \\
\text { family support }\end{array}$ & $-0.258^{\mathrm{b}}$ & $-0.211^{\mathrm{b}}$ & $-0.219^{\mathrm{b}}$ \\
\hline $\begin{array}{c}\text { Comprehend } \\
\text { support total } \\
\text { score }\end{array}$ & $-0.306^{\mathrm{c}}$ & -0.111 & -0.129 \\
\hline
\end{tabular}


It can be seen from Table 4 that physical (emotion) exhaustion, comprehension of family support, and emotional support enter the regression equation in turn, and the t-test has reached the level of significance, and physical (emotion) exhaustion has the largest interpretable amount. The comprehensive explanation of the three factors to the total score is $22.2 \%$.

\section{Multiple regression analysis of mental health, social support, and demographic variables on sports fatigue}

The thesis uses the total score of each factor of sports fatigue as the dependent variable and takes the total score of the various factors of mental health, the factors of social support, and 14 variables such as gender, age, education level, sports skill level, and family economic situation as independent variables, and conduct multiple Linear stepwise regression analysis (stepwise method). Model 6 has the highest coefficient of determination, and the analysis of variance has reached the significance level, as shown in Table 5.

It can be seen from Table 5 that the five variables of mental health total score, age, comprehension family support, sports skill level, and family economic conditions enter the regression equation in turn, and the t-test has reached the significant level. The comprehensive explanation of the five factors to the total score is $22.5 \%$.

\section{DISCUSSION}

\section{Sports fatigue is an important, relevant factor for athletes' mental health}

The results of this study show that the mental health level of elite athletes is closely related to the degree of sports fatigue, and the correlation

Table 4. Multiple regression analysis of sports fatigue, social support, and demographic variables on mental health.

\begin{tabular}{c|c|c|c|c|c|c}
\hline Model 3 & $\begin{array}{c}\text { Standard } \\
\text { regression } \\
\text { coefficient }\end{array}$ & $\boldsymbol{t}$ & $\mathbf{R}$ & $\mathbf{R 2}$ & $\begin{array}{c}\text { Adjusted } \\
\text { R2 }\end{array}$ & $\mathbf{F}$ \\
\hline $\begin{array}{c}\text { Physical, emotional } \\
\text { exhaustion }\end{array}$ & 1.822 & $4.380^{\mathrm{c}}$ & & & & \\
\hline $\begin{array}{c}\text { Understanding } \\
\text { family support }\end{array}$ & -1.027 & $-2.970^{\mathrm{b}}$ & & & & \\
\hline Subjective support & -0.983 & $-2.617^{\mathrm{b}}$ & 0.471 & 0.222 & 0.208 & $15.146 \mathrm{C}$ \\
\hline Remarks: a:P $<0.05 ; \mathrm{b}: \mathrm{P}<0.01 ; \mathrm{c}: \mathrm{P}<0.001$.
\end{tabular}

Table 5. Multiple regression analysis of mental health, social support, and demographic variables on the total score of exercise fatigue.

\begin{tabular}{|c|c|c|c|c|c|c|}
\hline Model 6 & $\begin{array}{l}\text { Standard } \\
\text { regression } \\
\text { coefficient }\end{array}$ & $t$ & $R$ & R2 & Adjusted R2 & $F$ \\
\hline $\begin{array}{l}\text { Total mental } \\
\text { health score }\end{array}$ & 0.137 & $4.301 \mathrm{c}$ & & & & \\
\hline age & 0.611 & $4.013 c$ & & & & \\
\hline $\begin{array}{l}\text { Understanding } \\
\text { family support }\end{array}$ & -0.366 & \multirow{2}{*}{$-2.468 b$} & & & & \\
\hline Sports skill level & 3.288 & & & & & \\
\hline $\begin{array}{l}\text { Family economic } \\
\text { conditions }\end{array}$ & -3.261 & $-2.78 a$ & 0.499 & 0.249 & 0.215 & $10.431 c$ \\
\hline
\end{tabular}

coefficients between most factors have reached a significant level (Table 1); besides, through the stepwise multiple regression analysis of the total mental health score, it is found that sports Physical (emotional) exhaustion in fatigue is an important predictor of the mental health of elite athletes (Table 4).

\section{Related influencing factors of sports fatigue}

Comprehend that family support and family economic conditions play a regulatory role through social support, an important external "buffer" in the stress process. Among them, team members with low-income family economic conditions may face financial pressure, pay more attention to material rewards such as money, and use monetary standards to measure sports performance. The law of "diminishing returns" in sports training can easily lead to the weakening of their motivation. Training enthusiasm is lost; players with good family financial conditions do not have financial pressure. On the contrary, they may receive financial support from their families and can devote themselves to sports.

\section{Social support is an important external "buffer"}

It is worth pointing out that there is a significant positive correlation between social support and the excitement state factor in mental health, which is not in line with the original hypothesis. This may be related to the special professional group of athletes, which are highly stressed and have arousal levels. It is closely related to sports performance and needs to be in a state of high excitement for a long time. Social support is an important external reason for maintaining a state of excitement.

\section{CONCLUSION}

Age, sports skill level, family economic conditions, comprehension of family support, and mental health are important predictors of sports fatigue for elite athletes. Therefore, it is recommended that sports teams focus on the sports fatigue of older elite athletes, have high technical levels, low-income family financial conditions, and have high mental health test scores, and adjust training plans and training loads appropriately according to the individual differences of these athletes. So that their physical and mental exhaustion can be fully recovered, and at the same time, psychological intervention should be actively adopted to allow athletes to learn self-adjustment and coping skills to avoid psychological exhaustion. Social support is an important external "buffer" in the stress process of elite athletes'training, in which comprehension family support and emotional support play a major regulatory role. Therefore, we call on society to give more extensive support to the highly stressed elite athletes group.

\section{ACKNOWLEDGMENTS}

The work was supported by the Research Fund for Humanities and Social Science of Universities of Shandong Province ( Department-level Project: J15WF18)

The author declare no potential conflict of interest related to this article

\section{REFERENCES}

1. Creswell JD, Lindsay EK, Villalba DK, Chin B. Mindfulness training and physical health: mechanisms and outcomes. Psychosom Med. 2019;81(3):224-32.

2. Grijota FJ, Muñoz D, Bartolomé I, Siquier-Coll J, Robles MC, Maynar M. Arsenic, cadmium and lead erythrocyte concentrations in men with a high, moderate and low level of physical training. Biol Trace Elem Res. 2020;195(1):39-45.

3. Martland R, Mondelli V, Gaughran F, Stubbs B. Can high-intensity interval training improve physical and mental health outcomes? A meta-review of 33 systematic reviews across the lifespan. J Sports Sci. 2020;38(4):430-69.
4. Craighead DH, Heinbockel TC, Hamilton MN, Bailey EF, MacDonald MJ, Gibala MJ, et al. Time-efficient physical training for enhancing cardiovascular function in midlife and older adults: promise and current research gaps. J Appl Physiol (1985). 2019;127(5):1427-40.

5. Zwinkels M, Verschuren O, de Groot JF, Backx FJG, Wittink H, Visser-Meily A, Takken T; Sport-2-Stay-Fit study group. Effects of high-intensity interval training on fitness and health in youth with physical disabilities. Pediatr Phys Ther. 2019;31(1):84-93.

6. Galea S, Merchant RM, Lurie N. The mental health consequences of COVID-19 and physical distancing the need for prevention and early intervention. JAMA Intern Med. 2020;180(6):817-18. 